\title{
Study of Extension Needs for Cattle Breeders Concerning the Common Diseases between Human and Animal and How to Prevent Them in Some Centers of El-Beheira Governorate \\ Hayam M.A. Hassieb ; A. A. Bekhiet and Dalia A. Kishk Extension and Rual Aevelopment Research

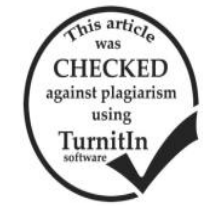

\section{دراسة الإحتياجات الإرشادية لمربي الماثية فيما يتعلق بالأمراض المشتركة بين الإنسان والحيوان وكيفية الوقاية

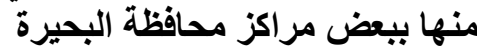

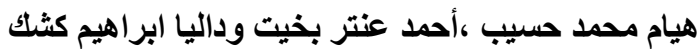 معهد بحوث الإرشاد الزراعى والتنمية الريفية \\ الملخص}

\begin{abstract}
يهذف هذا البحث بصفة أساسية إلى دراسة الإحتياجات الإرشادية لمربي الماثنية فيما يتعلق بالأمر اض المشتركة بين الإنسان والحيوان

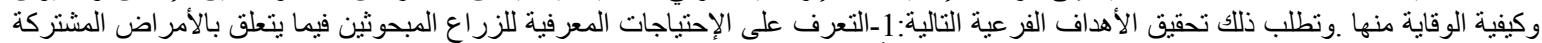

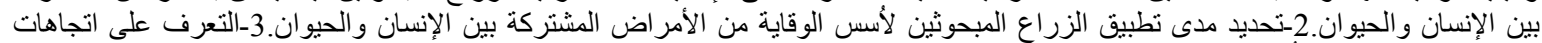

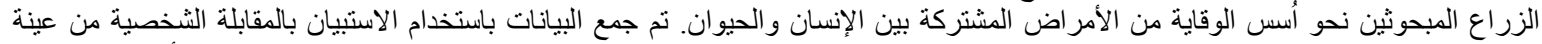

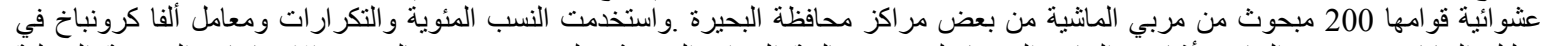

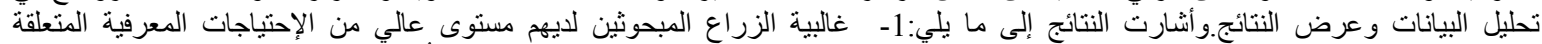

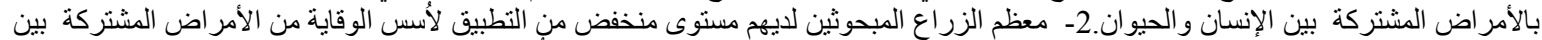

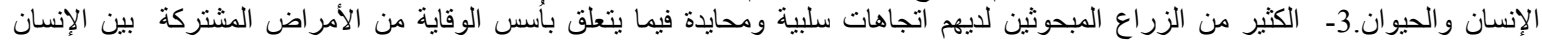

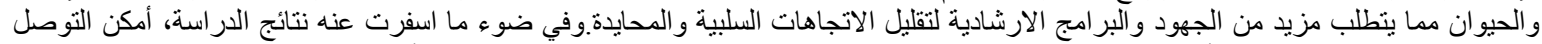

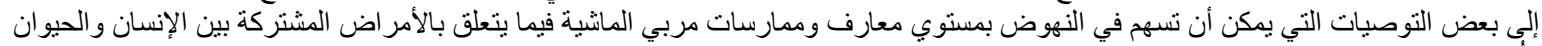

( http://www.yemeress.com/algomhoriah/2172076 )

\section{المقدمة و المشكلة البحثية}

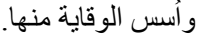

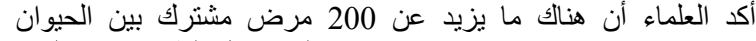

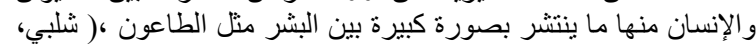

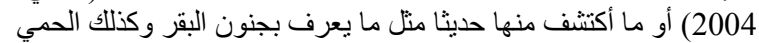

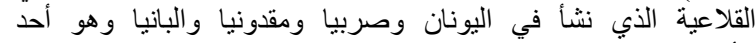

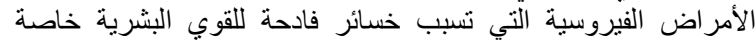

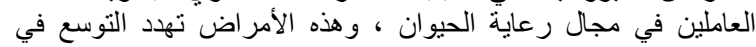

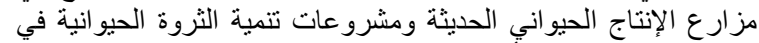

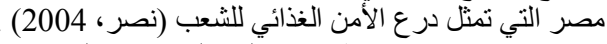

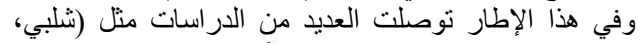

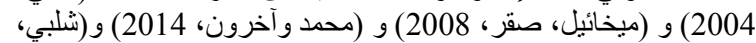

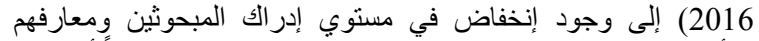

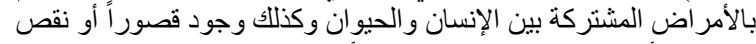
معرفي بأساليب الوقاية من هذه الأمراض المشتركة بين الإنس الإنسان

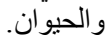

وبناء علي ما سبق يمكن القول بأن انخفاض مستوي الوعي

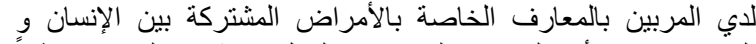

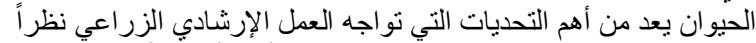

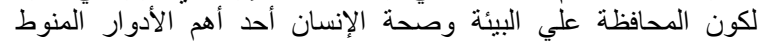

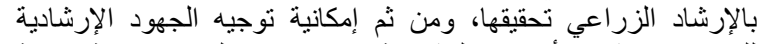

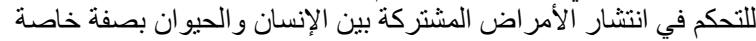

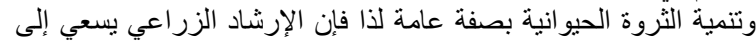

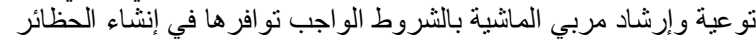

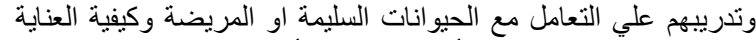

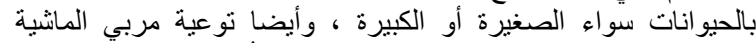

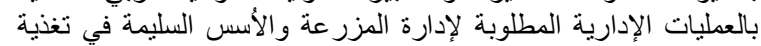

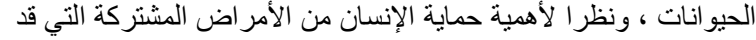

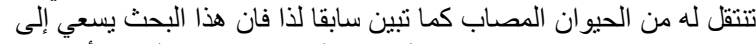

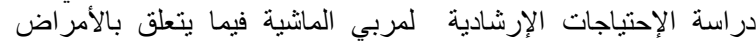

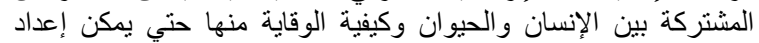

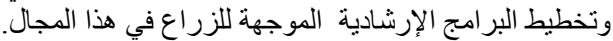
الأهداف البحثية

إستهدفت الدراسة بصفة أساسية دراسة الإحتياجات الإرشادية

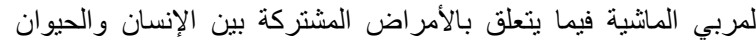
وكيفية الوقاية منها ببعض مر الاكز محافظة البحيرة وذللك من خلال تحقيق الأنيق

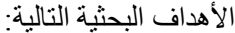

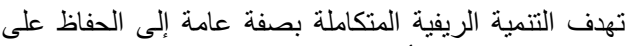

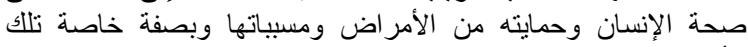

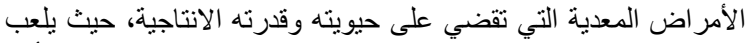

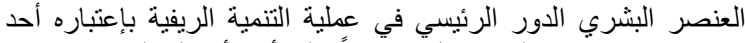

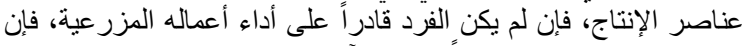

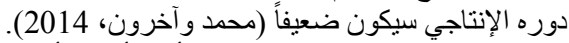

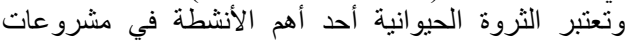

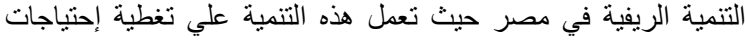

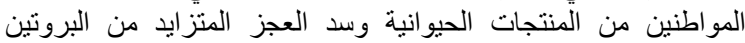

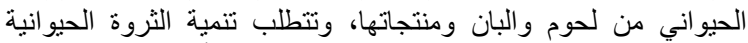

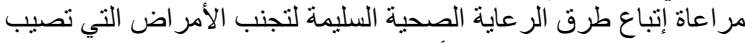

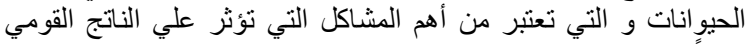

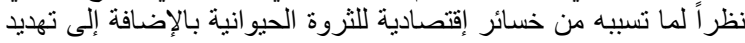

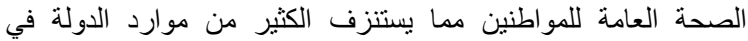

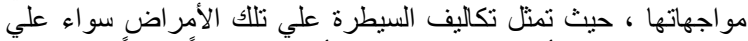

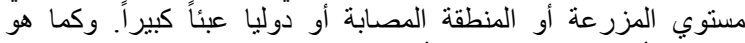

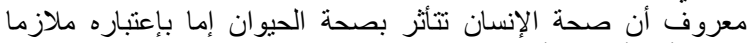

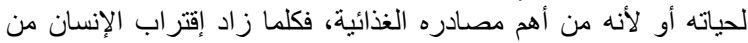

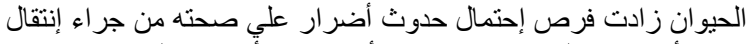

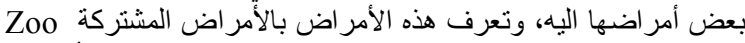

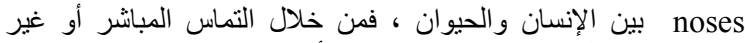

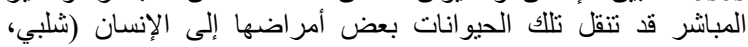

.(2004

الأمر الذي يتطلب التركيز على التوعية في مجال الصحة

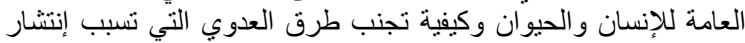

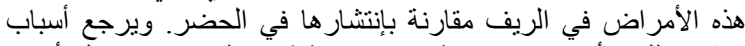

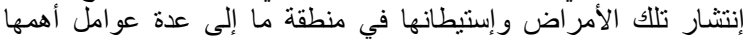

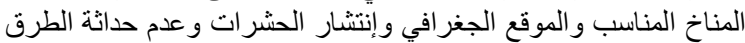

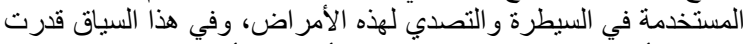

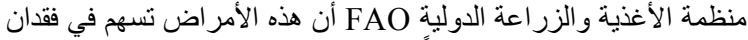

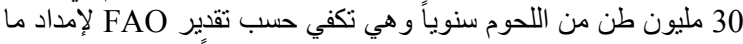

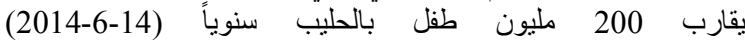
( http://www.alsabaah.iq)

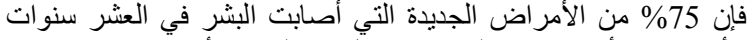

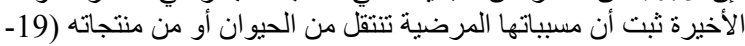

(2013-4 


\section{Hayam M. A. Hassieb et al.}

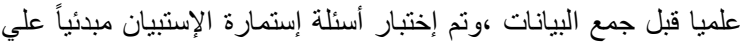

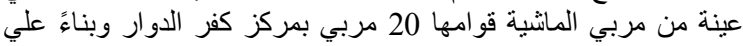

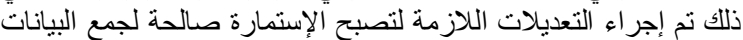
المطلوبة في صورتها النهائية وتم جمع بيانات البحثث خلال شهر يوليو لئي

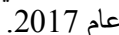

أسلوب تحليل البيانات

استخدمت الأساليب الإحصائية البسبطة مثل النسب المئوية

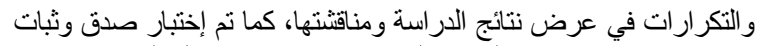

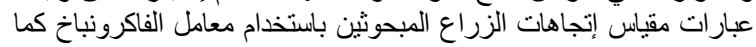

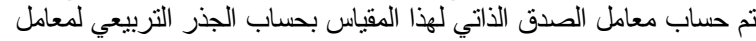

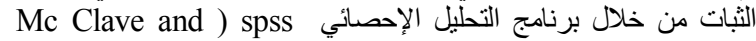

.(Sincich, 2006

التعريفات الإجرائية

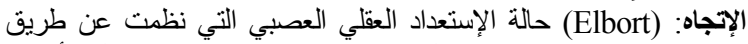

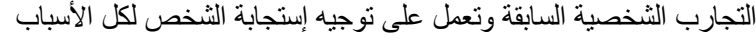
و والمو اقارب التي تتعلق بالإستعداد العقلي العصبي.

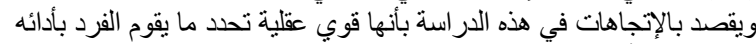

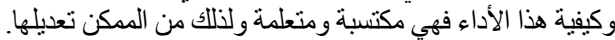

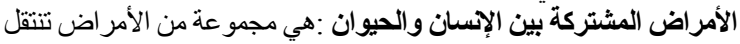

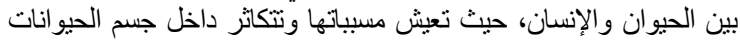

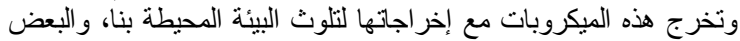

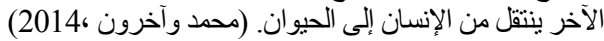

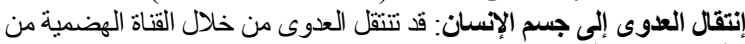

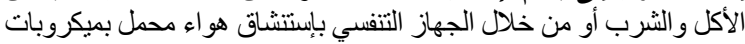

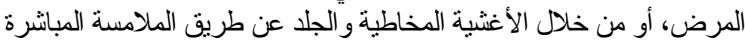
في وجود جروح أو خدوش بالجلد الإندا.

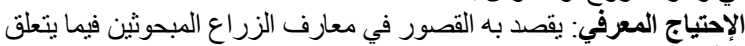

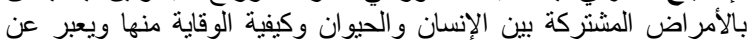
الإحتياج المعرفي للزراع المبن المبحوثين كالأتي:

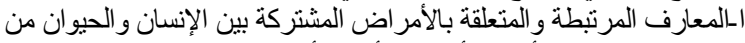

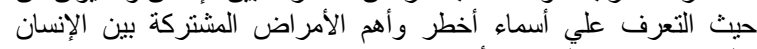

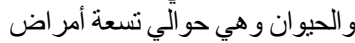

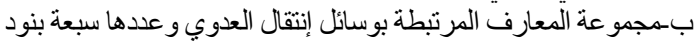

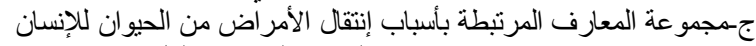

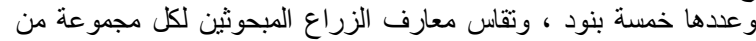

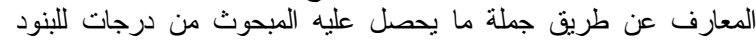

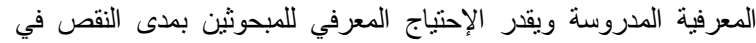
معارفهم المتعلقة بنلك البنود المعرفية المدروسة.

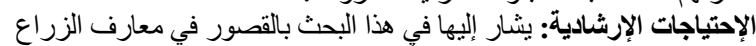

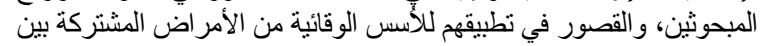

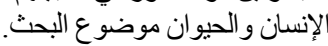
قياس الإذجاهات : يقاس بمجموع إستجابات الزراع المبان المبحوثين لمجموعة من

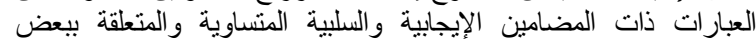
المعارف و الممارسات ذات الصلة بالأمر اض المشتركة بين الإنسات الإنسان و الحيوان

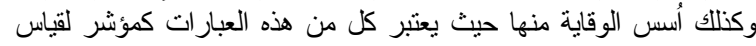

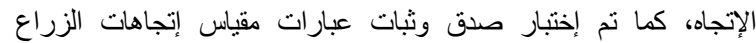

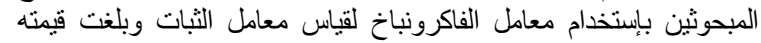

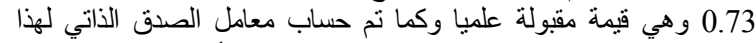

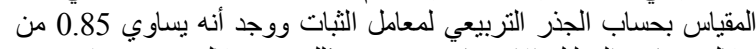

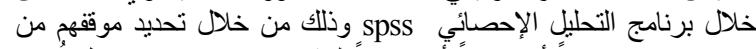

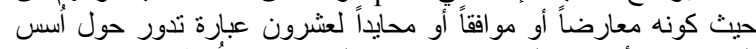

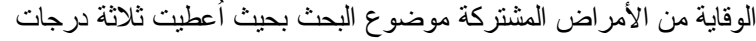

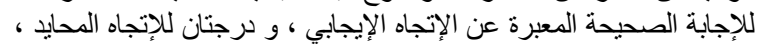

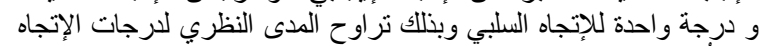
نحو أسس الوقاية من الأمراض المشتركة بين الإنسان و الحيوان بين ( 20 الإن

\section{النتائج البحثية والمناقشات}

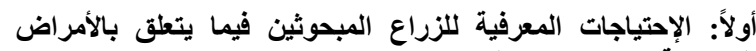

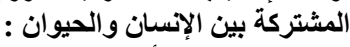

عدد الأمراض المشتركة بين الإنسان والحيوان حتى الإنى الآن

مائتي مرض تنتقل بين الإنسان والحيوان، وهذه الأمر اض أنثد خطراً
1. التعرف على الإحتباجات المعرفية للزراع المبحوثين فيما يتعلق

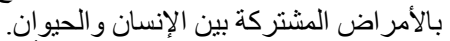

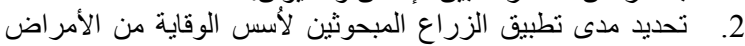
المشتركة بين الإنسان والحيو الزعان.

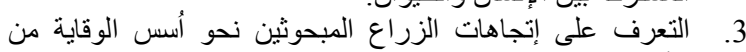

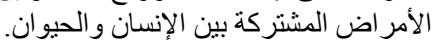
الإطار النظري

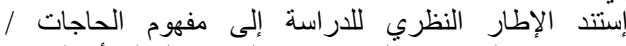

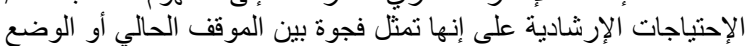

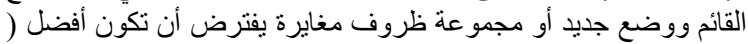

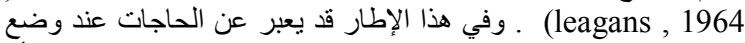

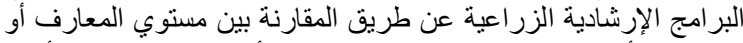

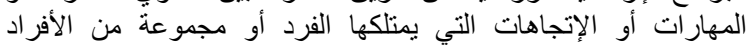

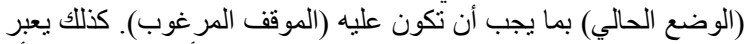

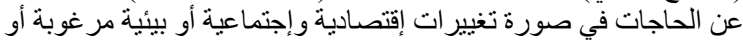

في صورة ممارسات يجب إتباعها (boyle and jahns, 1970).

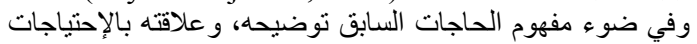

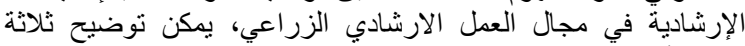

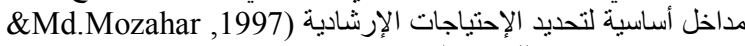
(Abdul Halim وذللك كما يلي:

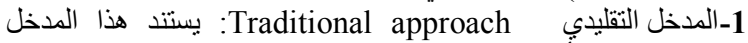
علي المدرب أو المرشد في تحديد الإحتياجات التدريبية / الإرشادية

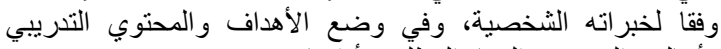
وأساليب الندريب والمهام المطلوب أدائها.

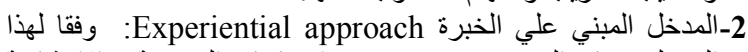
المذلل ، فإن المتدرب هو من يحدد إحتياجاته التنريبية / الإرشادية لهنية

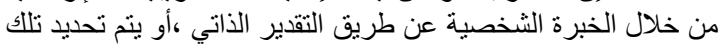

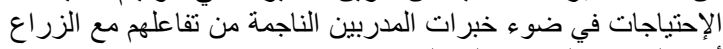
أنثاء المو اقف ألتدريبية المختلفة.

3- الدذخل المبني علي الأداء : Performance-based approach

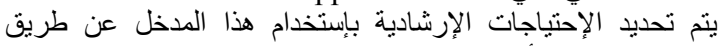

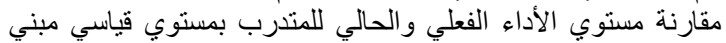

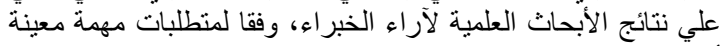
أو خطو ات محددة، ويتم ذلك عن طريق إلجر اء الاء الاختبارات.

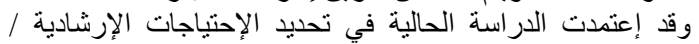

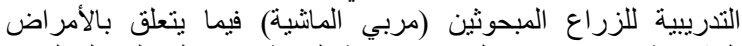

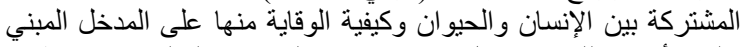

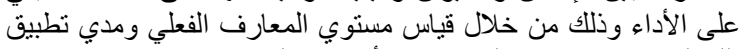
تلاك المعارف في كيفية الوقاية من الأمر اض اض المشتركة.

\section{الطريقة البحثية}

تم إجراء هذه الدر اسة في ثلاثة مر اكز من محافظة البحيرة تم

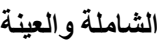

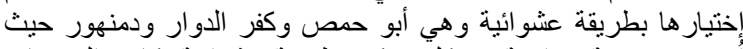

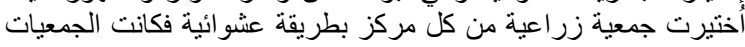

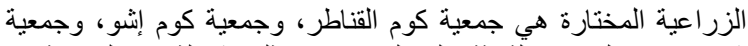

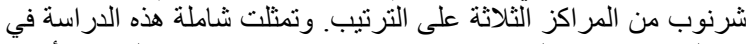

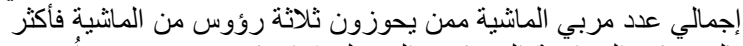

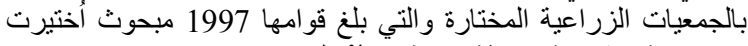

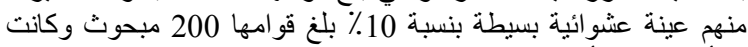

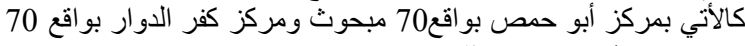
مبحوث ومركز دمنهور بو اقع 60 مبحوث.

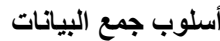

تم إستيفاء البيانات البحثية بإستخدام إستمارة الإستيان بالمقابلة الثخصية لتجميع عينة البحث و إثتملت إستمارة البحث على ثلاثلاثة محاور

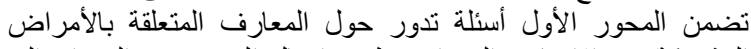

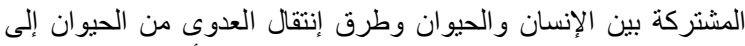

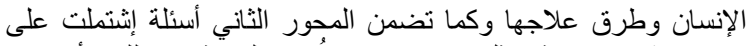

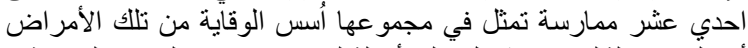

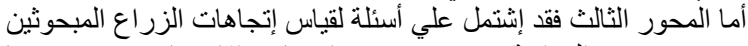

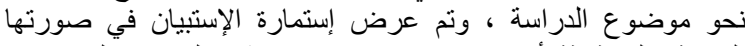
النهائية علي ثلاثة أساتذة متخصصين في الإرشاد الزراعي لمراجعتها 
المريضة في الأسواق، وتشير تللك النتائج إلى تدني نسب الملمين بالأسباب

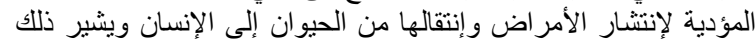

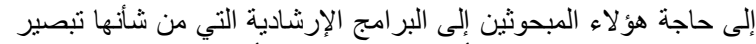

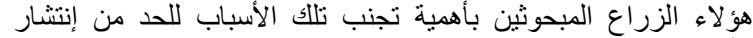
الأمر اض و إنتقالها من الحيوان للإنسان.

جدول 3. توزيع الزراع المبحوثين وفقاً لمعارفهم المتعلقة بأسباب إنتقال

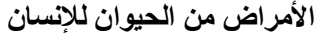

\begin{tabular}{|c|c|c|}
\hline$\%$ & عدد & أسباب إنتقال المرض \\
\hline 44 & 88 & عدم نظافة الحظيرة \\
\hline 39 & 78 & إنتشار الحشرات \\
\hline 35 & 70 & عدم إجر اء الكثف الدوري \\
\hline 19 & 38 & وجود الحظيرة داخل المنزل \\
\hline 11 & 22 & بيع الحيو انات المريضة في الأسو اق \\
\hline 2 & 4 & لا يعرف السبب \\
\hline
\end{tabular}

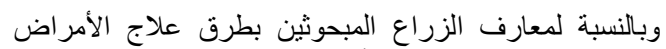

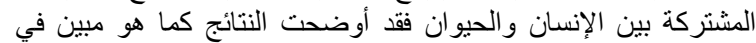

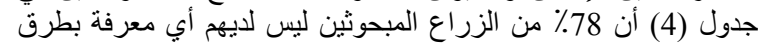

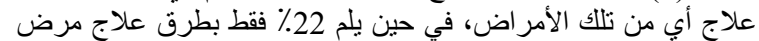

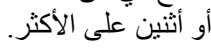

جدول 4. توزيع الزراع المبحوثين وفقاً لمعارفهم المتعلقة بطرق علاج

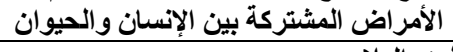

\begin{tabular}{|c|c|c|}
\hline$\%$ & عدد & المعرفة بطرق العلاج \\
\hline 22 & 44 & يعرف \\
\hline 78 & 156 & لا يعرف \\
\hline
\end{tabular}

ثانياً: ـمدى تطبيق المبحوثين لأسس الوقاية من الأمراض المشتركة

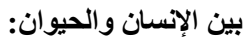

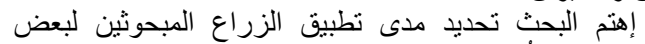

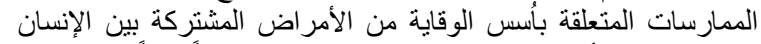

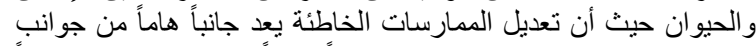

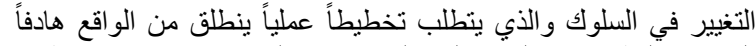

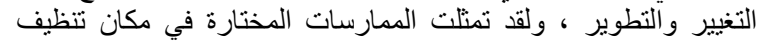

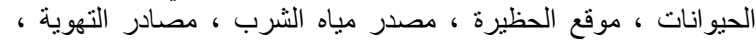

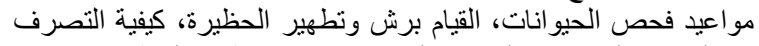

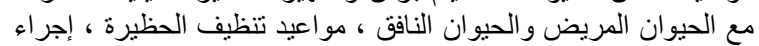

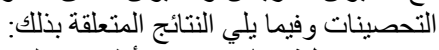

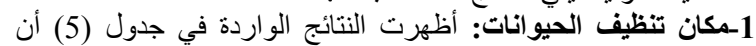

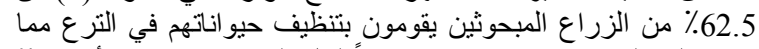

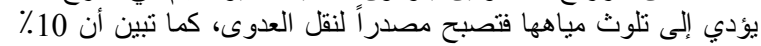

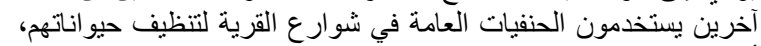

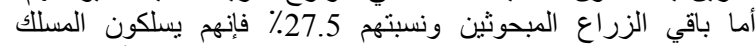

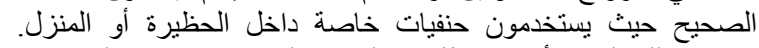

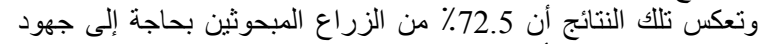

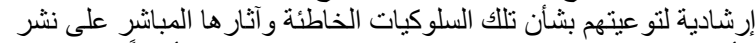
الأمر اض إلى الحيو إنات السئليمة بل وقد تمتد إلى الإنسان أيضاً.

جدول 5. توزيع الزراع المبحوثين وفقاً لمعارفهم المتعلقة بمكان تنظيف

\begin{tabular}{|c|c|c|}
\hline & & حيو اناتهم \\
\hline$\%$ & عدد & مكان التتظيف \\
\hline 62.5 & 125 & التر عة \\
\hline 22 & 44 & حنفية خاصة في المنزل \\
\hline 10 & 20 & حنفية عامة في الطريق \\
\hline 5.5 & 11 & حنفية خاصة في الحظيرة \\
\hline
\end{tabular}

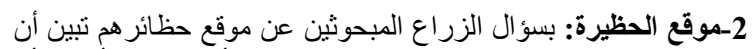

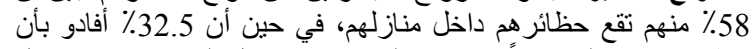

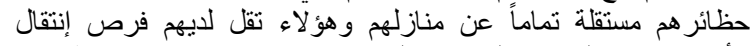

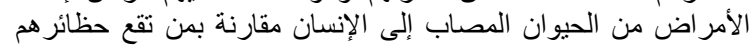

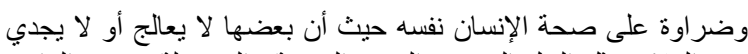

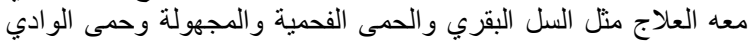

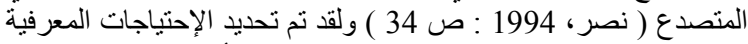

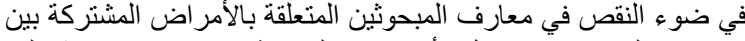

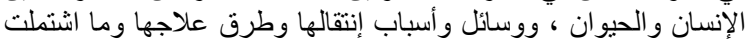

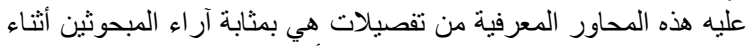

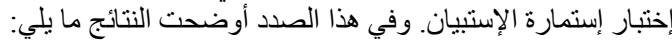

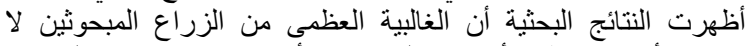

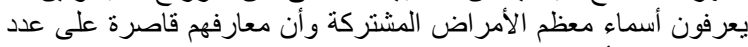

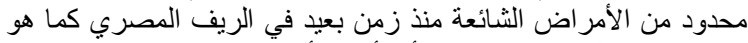

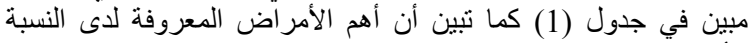

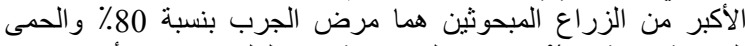

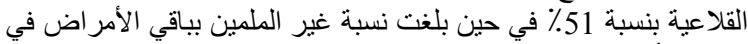

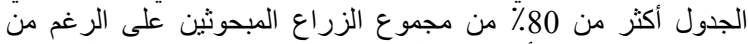

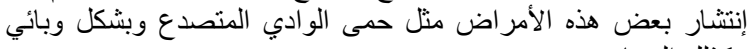

وكذلك السعار.

جدول 1. توزيع الزراع المبحوثين وفقاً لمعارفهم المتعلقة بأهم الأمراض المشتركة بين الإنسان والميوران

\begin{tabular}{|c|c|c|}
\hline$\%$ & عدد & إسم المرض \\
\hline 80.00 & 150 & الجرب \\
\hline 51.00 & 102 & الحمى القلاعية \\
\hline 48.00 & 96 & إلتهاب الضرع - إلتهاب الجلد العقدي \\
\hline 42.00 & 84 & السل و الدودة الكبدية \\
\hline 30.00 & 60 & القراع \\
\hline 25.00 & 50 & الدودة الشريطية \\
\hline 20.00 & 40 & البروسيلا - الجدري ـ حمى الو ادي المنصدع \\
\hline 10.00 & 20 & التيتانوس - جنون البقر \\
\hline 9.00 & 18 & السعار \\
\hline
\end{tabular}

وبسؤ ال الزراع المبحوثين عن وسائل إنتقال العدوى من الحيوان

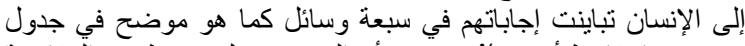

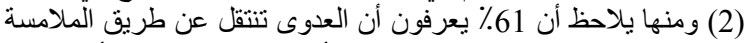

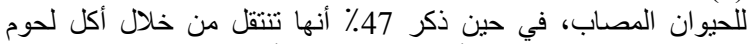

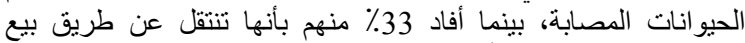
الحيو انات المصابة في الأسواق.

جدول 2. توزيع الزراع المبحوثين وفقاً لمعارفهم المتعلقة بوسائل إنتقال

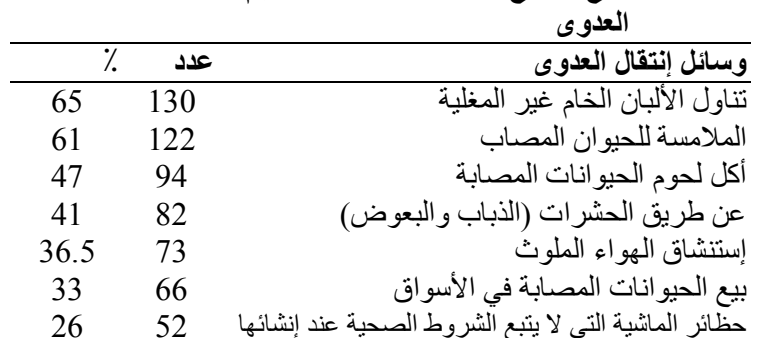

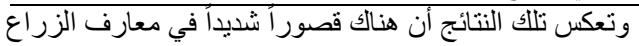

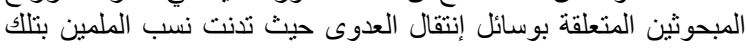

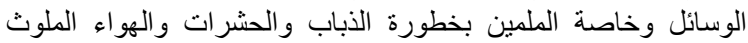
بمسببات الأمر اض. اض.

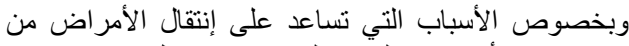

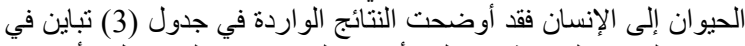

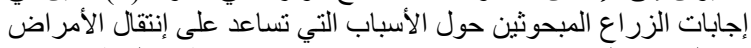

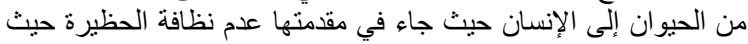

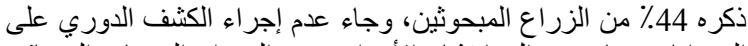

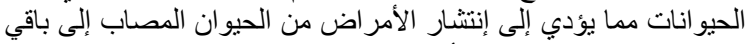

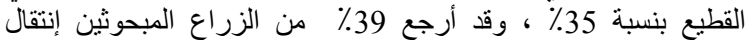

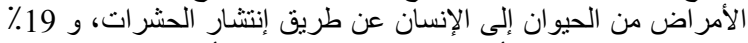

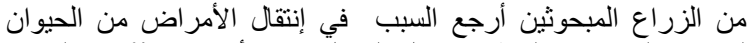

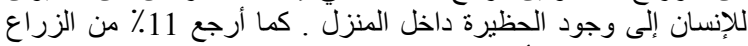
المبحوثين إنتشار الأمراض من الحيوان للإنسان إلى بيع الحئ الحيوانات الزيات 


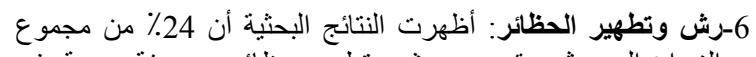

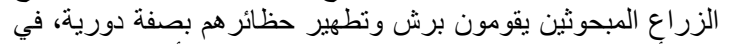
حين أن 63\% منهم يطهرونها بصفة غئرن غير منتظمة، أما النسبة الباقية و البالغة 23\% لا يقومون بتطهير حظائر هم مطلقاً كما هو مبين بجدول

جدول 10. توزيع الزراع المبحوثين وفقاً لمعارفهم المتعلقة بقيامهم بتطهير حظائر هم المير

\begin{tabular}{|c|c|c|}
\hline & & 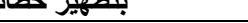 \\
\hline$\%$ & عدد & رش وتطهير الحظائر \\
\hline 63 & 126 & رش بصفة غير منتظمة \\
\hline 24 & 48 & رش بصفة دورية \\
\hline 23 & 46 & لا يقوم بالرش \\
\hline
\end{tabular}

وتثير تلك النتائج إلى أن أكثر من 85٪ من الزراع المبحوثين لا

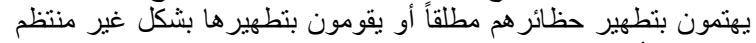

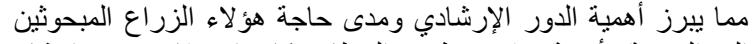

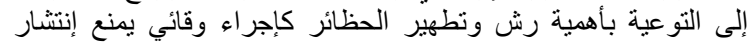

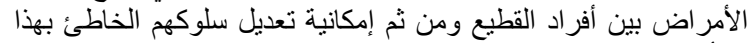

الثأن.

7-كيفية التصرف مع الحيوان المريض: أظهرت النتائج البحثية أن أكثر

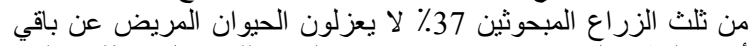

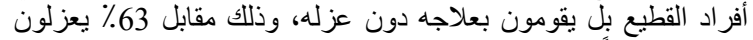

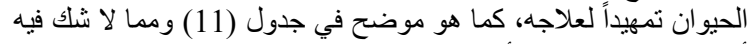

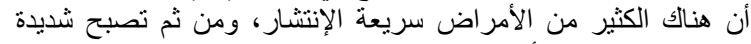

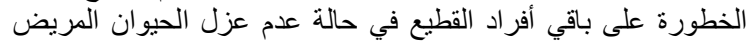

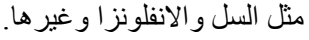

جدول 11. توزيع الزراع المبحوثين وفقاً لمعارفهم المتعلقة بقيامهم بعزل الحيوان المريض المبرئ

\begin{tabular}{|c|c|c|}
\hline$\%$ & عدد & عزل الحيوان المريض \\
\hline 63 & 126 & يقومون بالعزل \\
\hline 37 & 74 & لا يقومون بالعزل \\
\hline
\end{tabular}

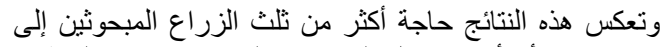

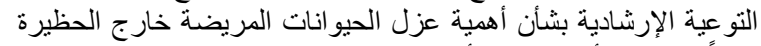
تجنباً لإنتشار الأمر اض بين أفراد ألفية عزل القطيع.

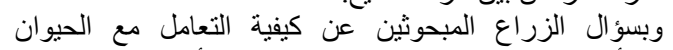

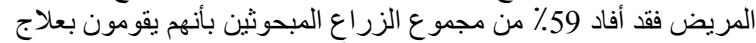

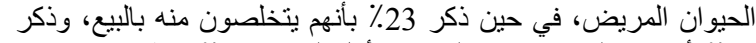

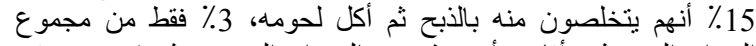

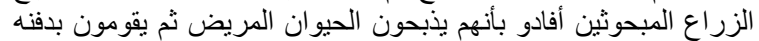

كما هو موضح بجدول (12).

جدول 12. توزيع الزراع المبحوثين وفقاً لمعارفهم المتعلقة بكيفية

\begin{tabular}{|c|c|c|}
\hline & \multicolumn{2}{|c|}{ التعامل مع الحيوان المريض } \\
\hline$\%$ & عدد & أوجه التصرف \\
\hline 59 & 118 & يعالجه \\
\hline 23 & 46 & يبيعه \\
\hline 15 & 30 & يذبحه \\
\hline 3 & 6 & يذبحه ثم يدفنه \\
\hline
\end{tabular}

وتنشير تللك النتائج إلى أن 38٪ من مجموع الزراع المبحوثين

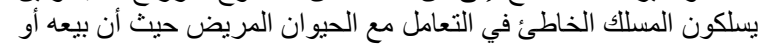

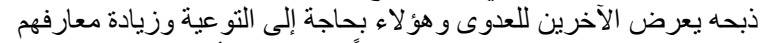

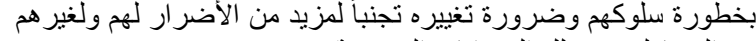

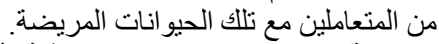

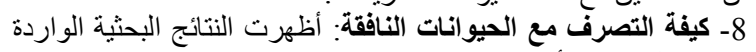

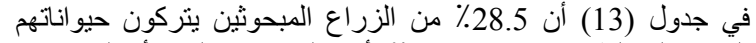

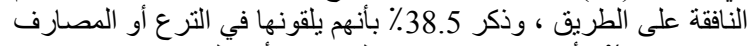

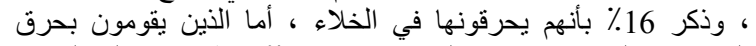

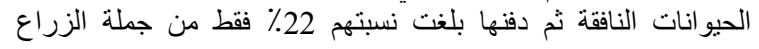

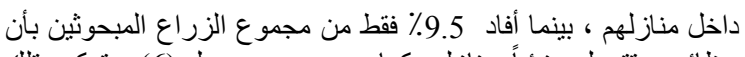

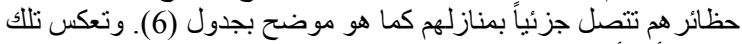

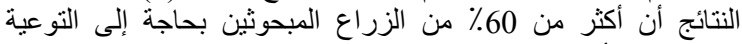

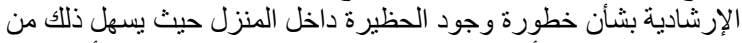

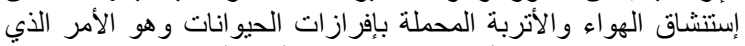

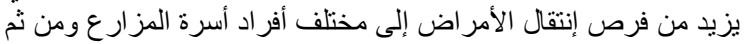

يعرض حياتهم للخطر.

جدول 6. توزيع الزراع المبحوثين وفقاً لمعارفهم المتعقة بموقع

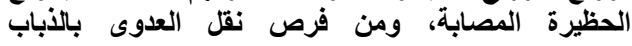

\begin{tabular}{|c|c|c|}
\hline$\%$ & عدد & موقع الحظيرة \\
\hline 58 & 116 & داخل المنزل \\
\hline 32.5 & 65 & مستقلة عن المنزل \\
\hline 9.5 & 19 & متصلة بالمنزل جزئياً \\
\hline
\end{tabular}

10- مصدر مياه شرب جرياً الحيوانات: أوضحت النتائج أن 30٪ فقط من المن مجموع الزراع المبحوثين بيلكون المسلك الصيون الصحيح لتوفير مياه

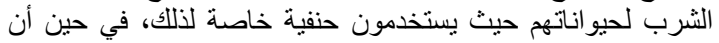

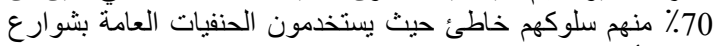

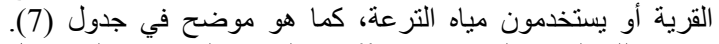

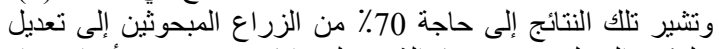

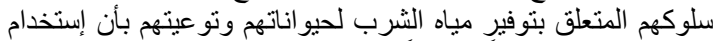

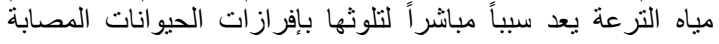

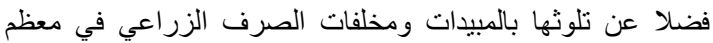
الأحيان وبذلك يمند الأثر الضار إلى الإنسان والصنات والحيوان.

جدول 7. توزيع الزراع المبحوثين وفقاً لمعارفهم المتعلقة بمصدر مياه شرب الحيوانات النيات

\begin{tabular}{|c|c|c|}
\hline$\%$ & عدد & مصدر مياه شرب الحيو انات \\
\hline 37.5 & 75 & التزرعة \\
\hline 32.5 & 65 & حنفية عامة \\
\hline 30 & 60 & حنفية خاصة \\
\hline
\end{tabular}

10- مصدر التهوية: أظهرت النتائج أن هناك تفاوتاً في إهنمام الزراع الزباع

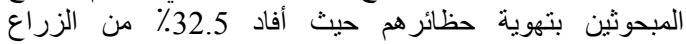

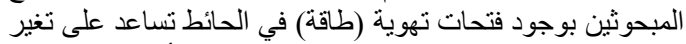

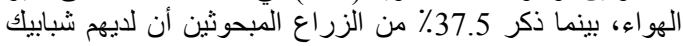

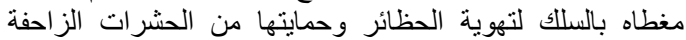

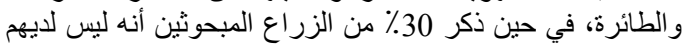

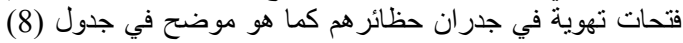

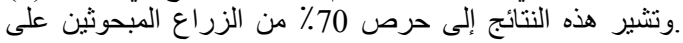

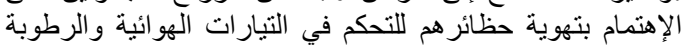
و الحرارة، مما يعكس إهتمامهم بالثشروط الصحية للتئة للحظيرة.

جدول 8. توزيع الزراع المبحوثين وفقاً لمعارفهم المتعلقة بوجود

\begin{tabular}{|c|c|c|}
\hline \multicolumn{3}{|c|}{ فتحات تهوية في حظائر هم } \\
\hline$\%$ & عدد & مصدر التهوية \\
\hline 37.5 & 75 & شباك مغطى بسلك \\
\hline 32.5 & 65 & فتحات في الحائط \\
\hline 30 & 60 & لا توجد \\
\hline
\end{tabular}

10- مواعيد القيام بفحص الحيوانات: أوضحت النتائج البحثية المبينة

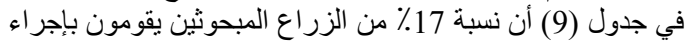

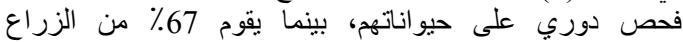

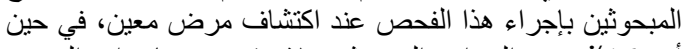

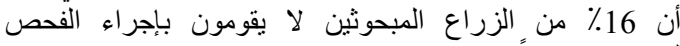
لحيو اناتهم نهائياً.

جدول 9. توزيع الزراع المبحوثين وفقاً لمعارفهم المتعلقة بمواعيد قيامهم بفحص حيواناتهم

\begin{tabular}{|c|c|c|}
\hline & \\
\hline$\%$ & عدد & مواعيد الفحص \\
\hline 67 & 134 & الفحص عند إكتشاف المرض \\
\hline 17 & 34 & الفحص بصفة دورية \\
\hline 16 & 32 & لا يجري الفحص \\
\hline
\end{tabular}




\section{J. Agric. Econom. and Social Sci., Mansoura Univ., Vol.8 (11), November,2017}

الإنسان حيث بلغت نسبة غير الملمين بأي من تلك الأسباب 55٪ من

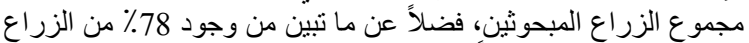

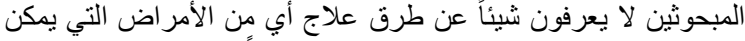

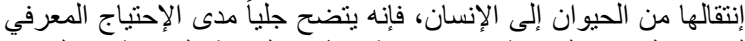

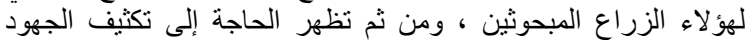

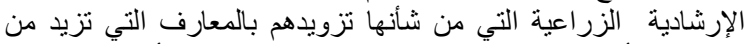

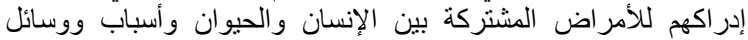

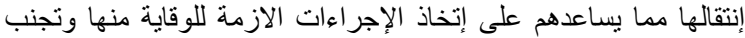

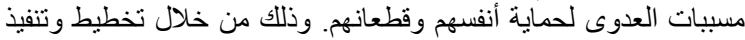

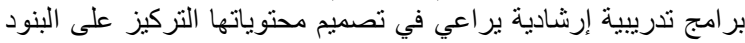

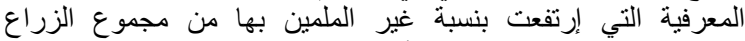

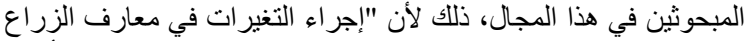
يعني إحداث تغيير في البنيان المعرفي لهان لهم، وإن إن إكتساب الفي الفرد للأفكار

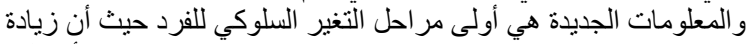

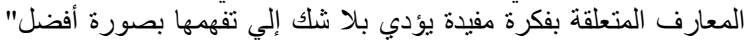

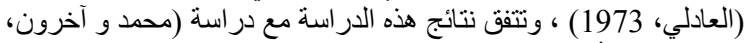

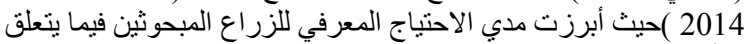

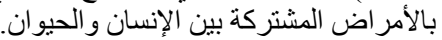

بـمدى تطبيق الزراع المبحوثين لأسس الوقائية من الأمراض المشتركة

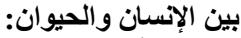

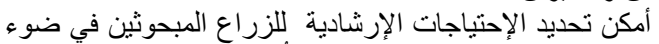

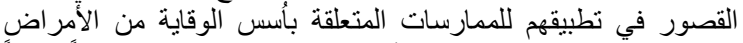

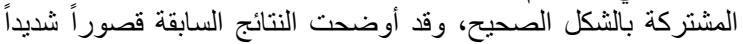

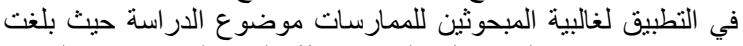

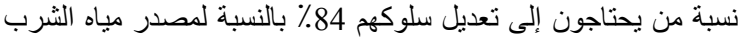

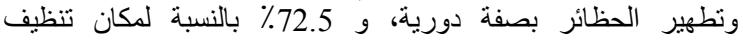

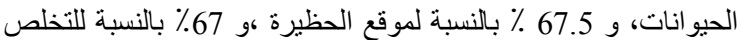

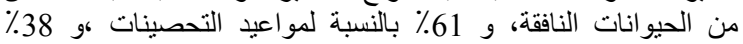

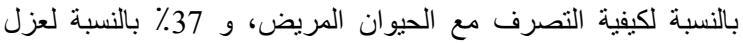
الحيو انات المريضة.

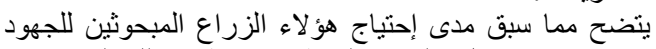

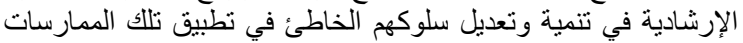

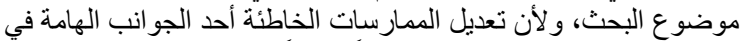

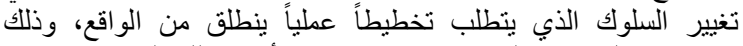

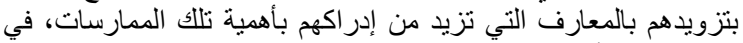

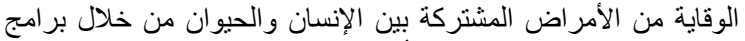

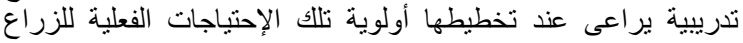

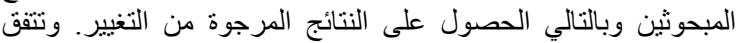

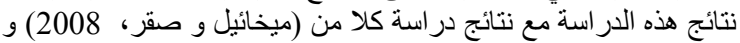

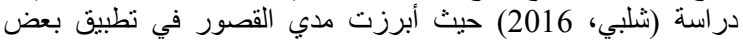

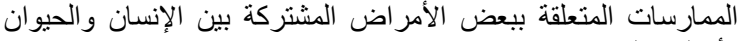

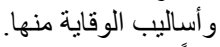

ثالثاً: إتجاهات الرثاية الزراع المبحوثين نحو أسس الوقاية من الأمراض

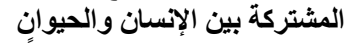

تلعب الإتجاهات دوراً هاماً في تحديد سلوك الأفراد حيث تؤثر

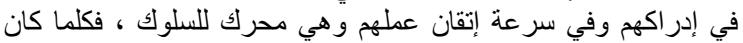

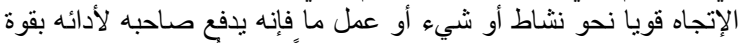

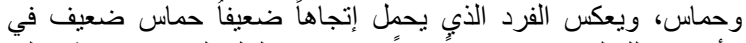

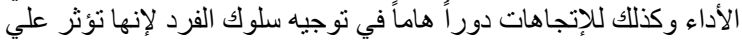

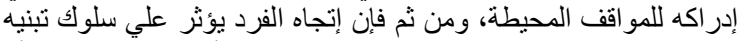

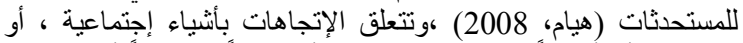

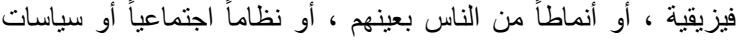

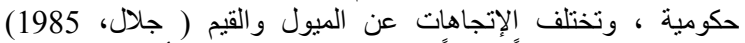

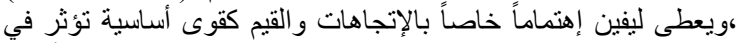

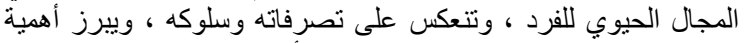

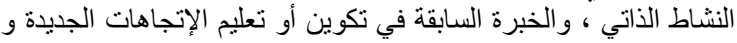

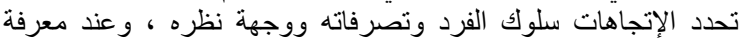

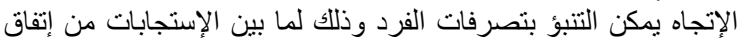

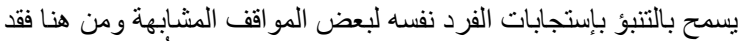

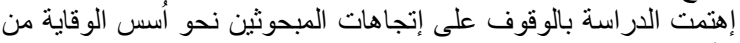

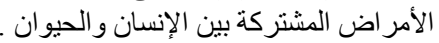

المبحوثين ويلاحظ من تلك النتائج أن 67٪ بتصرفون تصرفاً خاطئًا

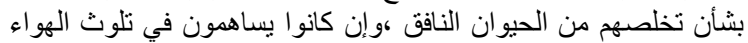

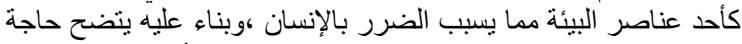

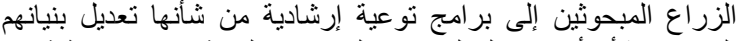

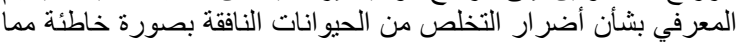
يزيد من فرص تعديلهم لسلوكهم الخاطئ بهذا الثنأن .

جدول 13. توزيع الزراع المبحوثين وفقاً لمعارفهم المتعلقة بتصرفاتهم مع الحيوانات النافقة النئ

\begin{tabular}{|c|c|c|}
\hline$\%$ & عدد & أوجه التصرف \\
\hline 38.5 & 77 & الإلقاء في الترع و المصارف \\
\hline 28.5 & 57 & الإلقاء في الطريق \\
\hline 22 & 44 & الحرق ثم الدفن \\
\hline 16 & 32 & الحرق في الخلاء \\
\hline
\end{tabular}

9-14واعيد تنظيف الحظيرة: أظهرت النتائج البحثية الواردة في جدول

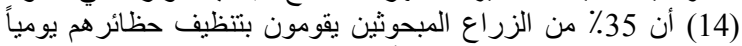

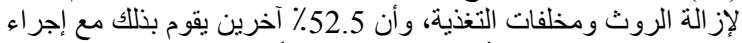

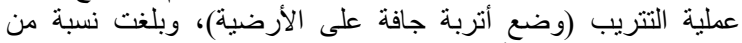
ينظفون حظائر هم كل أسبوع 7.5 أتربة جافة وبلغت نسبة من ينظفون حظائر هم كلما تطلب الأمر ذلك 5\% فقط من مجموع الزر أع اع المبحوثين.

جدول 14. توزيع الزراع المبحوثين وفقاً لمعارفهم المتعلقة بمواعيد تنظيفهم لحظائر هم

\begin{tabular}{|c|c|c|}
\hline$\%$ & عدد & مواعيا التنظيف للحظائر \\
\hline 52.5 & 105 & يوميا مع التتريب \\
\hline 35 & 70 & يومياً . \\
\hline 7.5 & 15 & إسبو عياً \\
\hline 5 & 10 & كلما تطلب الأمر \\
\hline
\end{tabular}

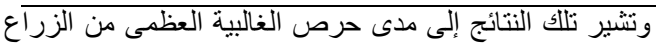

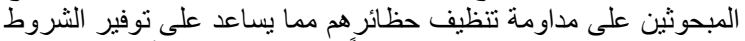

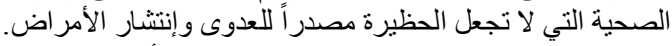

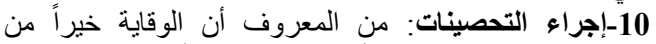

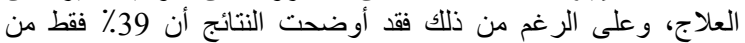

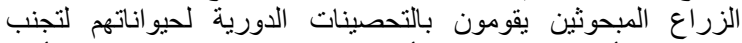

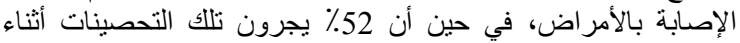

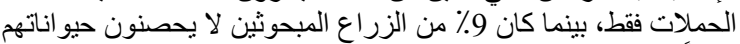

نهائياً كما هو موضح في جدول (15).

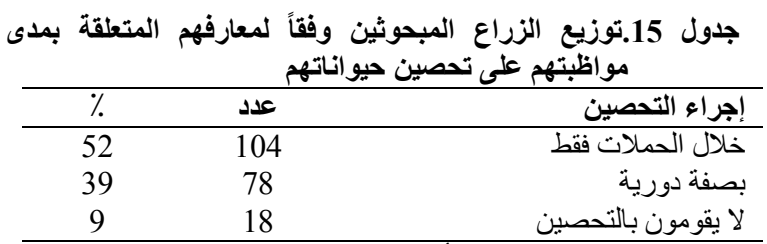

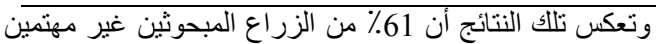

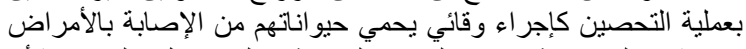

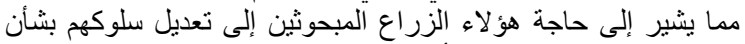

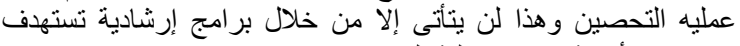

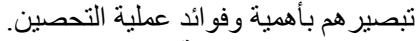

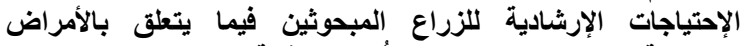

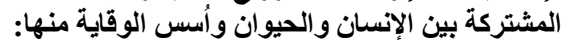

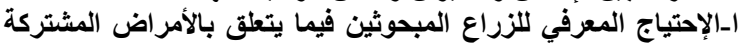

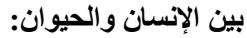

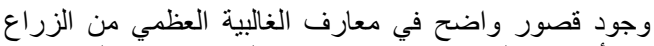

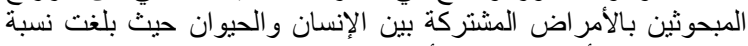

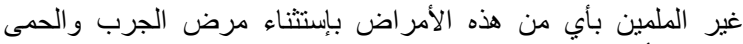

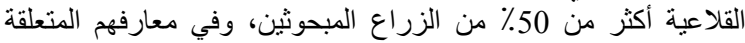

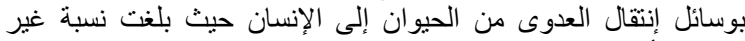

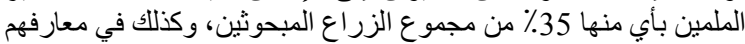

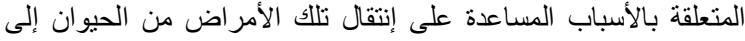




\section{Hayam M. A. Hassieb et al.}

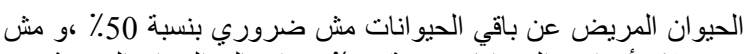

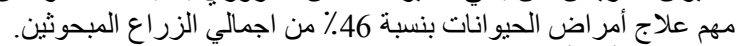

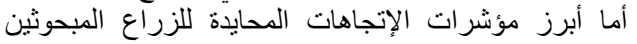

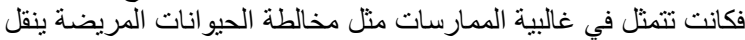

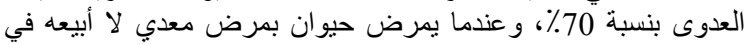

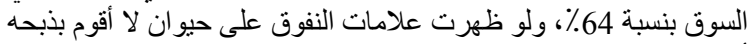

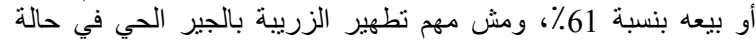
الأوبئة بنسبة 55٪ من إجمالي الزراع المبحوثين.

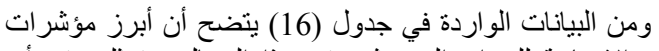

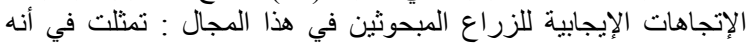

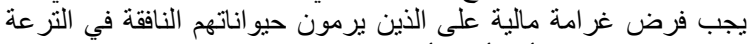

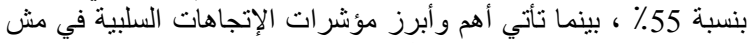

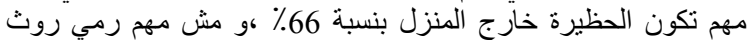

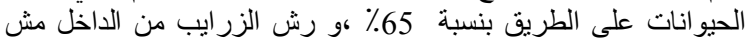

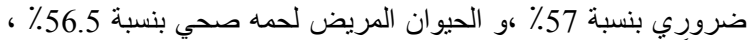
وأيضاً الإرشاد البيطري غير مهم لصحة الحيوان بنسبة 50٪ ،و فصل

جدول 16. توزيع الزراع المبحوثين وفقا لارجة إتجاهاتهم نحو أسس الوقاية من بعض الأمراض المشتركة بين الإنسان والحيوان

\begin{tabular}{|c|c|c|c|c|c|c|}
\hline$\%$ & الإلجباه & $\%$ & الإتجاه الحيادي & $\%$ & الإلإجابي & 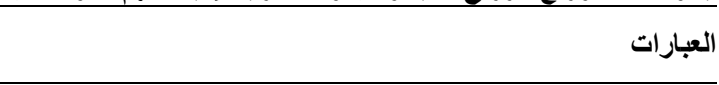 \\
\hline 66 & 132 & 15 & 30 & 17 & 38 & مش مهم تكون الحظيرة خارج المنزل م \\
\hline 65 & 130 & 26 & 52 & 9 & 18 & مش مهم رمي روث الحيوانات على الطريق \\
\hline 57 & 114 & 35 & 70 & 8 & 16 & رش الزر ايب من الداخل مش ضروري \\
\hline 56.5 & 113 & 34.5 & 69 & 9 & 18 & الحيو ان المريض لحمه صحي \\
\hline 50 & 100 & 35 & 70 & 15 & 30 & الإرشاد البيطري غير مهم لصحّة الحيوان \\
\hline 50 & 100 & 30 & 60 & 20 & 40 & فصل الحيوان المريض عن باقي الحيو انات مش ضروري \\
\hline 46 & 92 & 45 & 90 & 9 & 18 & مش مهم علاج أمر اض الحيوانات \\
\hline 45 & 90 & 45 & 90 & 10 & 20 & الحيو انات تستحم في التر عة مش مهم \\
\hline 43 & 86 & 51 & 102 & 6 & 12 & لو مات حيوان مريض أرميه على الطريق \\
\hline 40 & 80 & 45 & 90 & 15 & 30 & تنظيف الحظيرة مهم يومياً ت \\
\hline 39 & 78 & 55 & 110 & 6 & 12 & مش مهم تطهير الزريبة بالجير الحي في حالة الأوبئة \\
\hline 35 & 70 & 45 & 90 & 20 & 40 & المربي الثاطر يعطي علاج الديدان 3مرِات سنوياً \\
\hline 30 & 60 & 30 & 60 & 40 & 80 & المربي الشاطر يحصن الحيو انات من الأمر اض \\
\hline 27 & 54 & 64 & 128 & 9 & 18 & عندما يمرض حيو ان بمرض معدي لا أبيعه في السوق \\
\hline 25 & 50 & 45 & 90 & 30 & 60 & 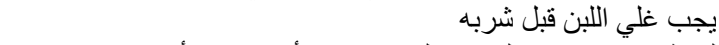 \\
\hline 17 & 38 & 61 & 122 & 20 & 40 & لو ظهرتً علامات النفوق على حيوان لا أقوم بذبحه أو بيعه \\
\hline 13 & 26 & 70 & 140 & 17 & 34 & مخالطة الحيو انات المريضة ينقل العدوى \\
\hline 11 & 22 & 50 & 100 & 39 & 78 & تلعب الحشر ات دور كبير في نقل الأمر اض \\
\hline 10 & 20 & 45 & 90 & 45 & 90 & مش ممكن أبيع لبن حيو انات مريضة \\
\hline 4 & 8 & 41 & 82 & 55 & 110 & يجب فرض غر امة مالية على الذين برمون حيو اناتهم النافقة في الترعة \\
\hline
\end{tabular}

3-ضرورة زيادة الرقابة على الأسواق للتأكد من سلامة وجودة اللحوم

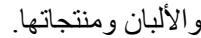

\section{المراجع}

أسماء حامد شلبي -معرفة مربى الماثشية بالإجر اءات الوقائية للسيطرة

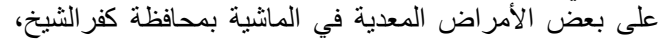

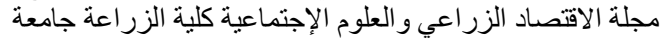

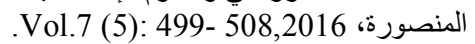
صلاح أحمد محمود محمد وآخرون -معرفة مربى الماثشية بالأمراض

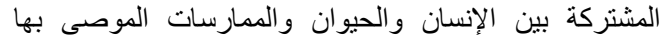

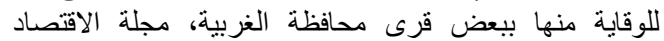

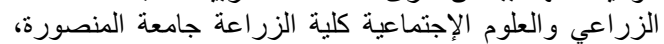
. Vol.5(12), December, 2014

إميل صبحي ميخائيل، زغلول محمد علي صقر -إدراك مربي الماثية

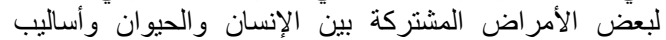

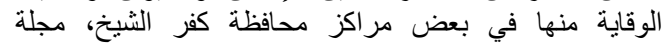
الإسكندرية للتبادل العلمي - مجلد 29 العدد 4 أكتوبر 2008 العنة إبر اهيم وجيه محمود - التعلم أسسه ونظرياته وتطبيقاته - مكتبة الأنس الأنجلو المصرية - القاهرة - 1976.

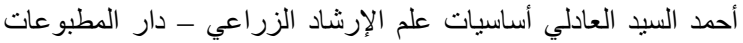

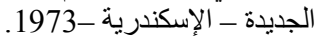

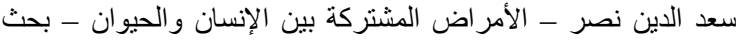

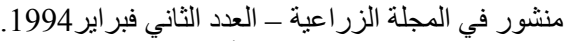

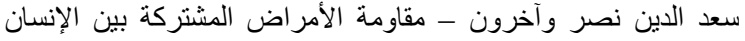

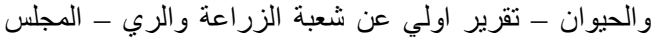

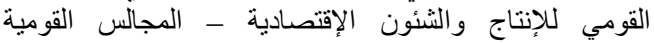
المتخصصة 2004الموقع الاليكتروني الإني

\%D9\%86http://www.academia.edu/4067100/A7

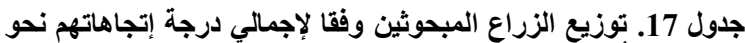

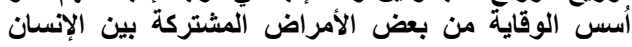

\begin{tabular}{|c|c|c|}
\hline & \multicolumn{2}{|c|}{ والحيوان } \\
\hline$\%$ & عدد & فئات الاتجاه \\
\hline 36.6 & 73 & سلبي 20-28 \\
\hline 43.4 & 87 & حيادي 29-37 \\
\hline 20 & 40 & إيجابي 38 فأكثر \\
\hline 100 & 200 & المجموع \\
\hline
\end{tabular}

ومن البيانات الواردة في جدول (17) يتضح من إجابات الزراع

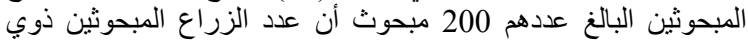

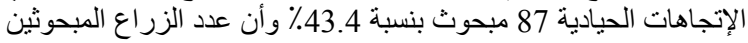

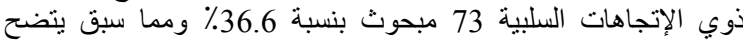

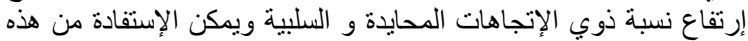

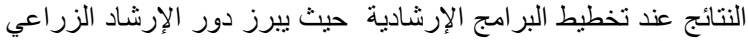

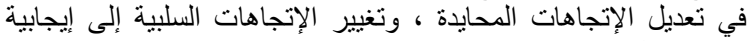

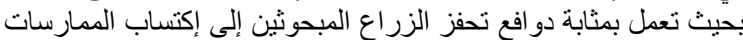
التي من شأنها تحقيق الوقاية من الأمراض المشتركة المثن بين الإنسان

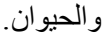
التوصيات

نظر اً لما أظهرته الدراسة من وجود إحتباجات إرشادية ملحة الإنة

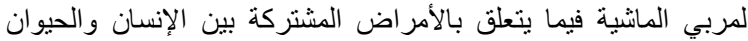

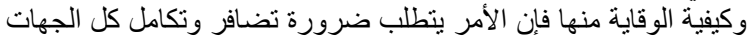

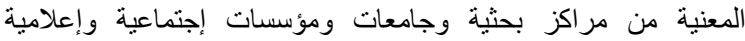

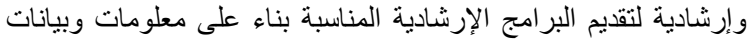
و اقعية الامر الذي يتطلب الإجراءيم الإدات التالية:

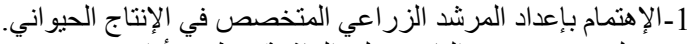
2-تفعيل دور صندوق التامين على المانشية وتطوير أدائه. 
Boyle, patricand Jahns, Irwin. (1970) "program development and Evaluation".In : Handbook of Adult education .Edited by Rober tm. Smith; publishing company, inc., NewYork.

Abdulhalim and Md. MozaharAl (1997) :"Training and Professional Development" in: Improving Agricultural Extension .Edited by Burton E. Swanson, Robert P. Bentz, and Andrew J. sofranko, FAO, Rome.

Mc clave, J and Sincich, T, (2006): statistics, 10 Edition, Pearson Education, Inc. Pearson prentice Hall upper saddle River, New jersey, U.S.A

http://www.yemeress.com/algomhoriah/2172076

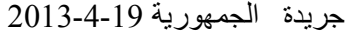

http://www.alsabaah.iq/ArticleShow.aspx?ID=72683 2014-6-14 جريدة الصباح العر اقية

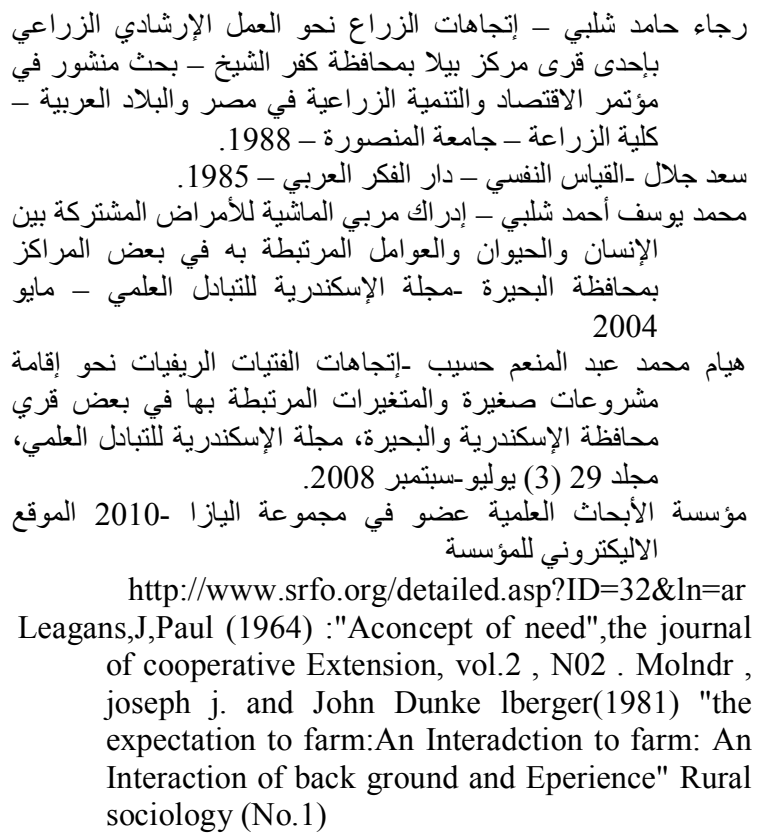
of cooperative Extension, vol.2 , N02 . Molndr, joseph j. and John Dunke lberger(1981) "the expectation to farm:An Interadction to farm: An Interaction of back ground and Eperience" Rural sociology (No.1)

\title{
Study of Extension Needs for Cattle Breeders Concerning the Common Diseases between Human and Animal and How to Prevent Them in Some Centers of El-Beheira Governorate Hayam M.A. Hassieb ; A. A. Bekhiet and Dalia A. Kishk Extension and Rual Aevelopment Research
}

\begin{abstract}
This research aimed to study the extension needs of cattle breeders concerning the common diseases between human and animal and how to prevent them. The study was carried out to achieve the following objectives: To identify the knowledge needs of the respondents concerning the common diseases between human and animal. To knowledge the extent to which respondents applied the foundations of prevention of common diseases between human and animal. Identify the attitudes of respondents towards foundation of prevention of common diseases between human and animal. Data were collected by questionnaire through personal interviews with a random sample consisted of zoo cattle breeders from some centers of El Beheira governorate. Percentage, frequencies and Alpha Cronbach factor were used in analyzing the data. Results indicated the following: $80 \%$ of respondents had high level of knowledge needs concerning the common diseases between human and animal. Most of respondents had low level of Appling the foundation of prevention of common disease between human and animal. Negative and neutral attitudes towards foundation of prevention of common disease between human and animal were observed among most of respondents which highlights the importance of the role of agricultural extension to change the neutral and negative trend to a positive one.
\end{abstract}

